\title{
Low-Carbohydrate Diets in Korea: Why Does It Matter, and What Is Next?
}

\author{
Kyungho $\mathrm{Ha}^{1}$, YoonJu Song ${ }^{2, *}$ \\ ${ }^{1}$ Department of Food Science and Nutrition, Jeju National University, Jeju; ${ }^{2}$ Department of Food Science and Nutrition, The Catholic University of Korea, Bucheon, \\ Korea
}

In recent years, low-carbohydrate diets have become highly popular in Korea as a means to lose weight. People following this regime believe that fat and protein can be consumed in unlimited quantities, as long as carbohydrate intake is strictly restricted. However, low-carbohydrate diets are more complex than simply reducing carbohydrate intake. Meta-analyses of randomized controlled trials revealed that low-carbohydrate diets are at least as effective as low-fat diets in terms of weight loss, but their cardiovascular effects vary. Low-carbohydrate diets confer more beneficial effects on weight loss and lipid profiles such as triglycerides and high-density lipoprotein cholesterol but exhibited detrimental effects on lipid profiles such as total and low-density lipoprotein cholesterol. Korean diets are typically high in carbohydrates, where carbohydrate intake is in the range of 50\%$80 \%$ of total energy. Within this range of carbohydrate intake, high carbohydrate intake was associated with an increased risk of elevated triglyceride and high-density lipoprotein cholesterol levels but with a reduced risk of elevated total and low-density lipoprotein-cholesterol levels. The optimal range of carbohydrate intake was depicted by a U-shaped relationship between carbohydrate intake and mortality, with $50 \%-60 \%$ of energy from carbohydrates having the lowest mortality risk. The distribution of macronutrients varied greatly according to age and sex groups in Korea. There is no single diet that can be recommended to all individuals, especially if focusing only on the quantity of macronutrients as opposed to their quality. The health benefits of low-carbohydrate or low-fat diets may depend on the source of protein and fat and the carbohydrate quality.

Key words: Low-carbohydrate diet, Low-fat diet, High-protein, Cardiometabolic risk factors, Obesity, Metabolic syndrome

\section{INTRODUCTION}

In recent years, low-carbohydrate (low-carb) diets have gained popularity as an alternative to conventional low-fat diets for weight loss. Among them, the Atkins diet has become one of the most successful low-carb diets, in which carbohydrate intake is strictly restricted, while protein and fat intake are unlimited; paradoxically, this promotes weight loss. ${ }^{1,2}$ Numerous studies have since compared the effects of low-carb vs. low-fat diets. Meta-analyses of randomized controlled trials (RCTs) revealed that low-carb diets are at least as effective as low-fat diets in terms of weight loss, but their cardiovascular effects vary in diverse populations. ${ }^{3-6}$

Academic discussions regarding the effects of low-carb diets on short-term weight loss and health outcomes were already rife when television programs promoting low-carb, high-fat diets aired in Korea in 2016 and received huge public attention, triggering the lowcarb diet trend in Korea. As a result, many people throughout Korea eat butter and pork belly without hesitation, believing that fat and protein can be consumed in unlimited quantities as long as carbohydrate consumption is restricted. However, low-carb diets are more complex than simply reducing carbohydrate intake.

The low-carb diet trend probably gained traction because of the

Copyright @ 2021 Korean Society for the Study of Obesity

(a) This is an Open Access article distributed under the terms of the Creative Commons Attribution Non-Commercial License (https://creativecommons.org/licenses/by-nc/4.o/) which permits unrestricted non-commercial use, distribution, and reproduction in any medium, provided the original work is properly cited. 
ability to consume high amounts of fat while still achieving weight loss. The low-fat message has long been emphasized in the dietary guidelines of several countries, being a key factor in the prevention and management of obesity and cardiovascular disease. However, the fact that very low-fat diets accompany high carbohydrate intake and that excessive carbohydrate intake is associated with increased cardiometabolic risk factors has been overlooked. Similarly, very low-carb diets are associated with increased cardiometabolic risk factors. Several reports have found that very low-fat diets or very low-carb diets are not desirable, either in terms of overall nutritional status or in reducing cardiometabolic risk factors. ${ }^{7,8}$

Carbohydrate intakes differ according to dietary cultures. Korean diets are typically high in carbohydrates because they are often ricebased with several plant-based foods. A study comparing the diets of U.S. and Korean adults found that the average carbohydrate intake was $65 \%$ of energy in Korean adults and 50\% in adults from the U.S. ${ }^{9}$ In Korea, the recommended intake of dietary carbohydrates is higher than that of the U.S. The acceptable macronutrient distribution range (AMDR) of carbohydrates in Korea was 55\%$70 \%$ until 2010 and was updated to $55 \%-65 \%$ in $2015 .{ }^{10}$ The U.S. AMDR of dietary carbohydrates is $45 \%-60 \%{ }^{11}$ This highlights differences in the notion of low-carb diets among different countries because carbohydrate intakes are population-specific.

Because the low-carb diet trend has only recently been introduced to Korea, few studies have investigated the extent to which carbohydrate intake should be reduced and fat and protein increased in Korean diets to prevent and manage obesity and cardiovascular disease. In this review, we compared the effects of low-carb diets and low-fat diets on cardiometabolic risk factors using recent meta-analyses. Furthermore, we summarized the associations between dietary carbohydrate intake and cardiometabolic risk factors in Korean populations and discussed the optimal carbohydrate intake and future directions for dietary research.

\section{THE EFFECTS OF LOW-CARB AND}

\section{LOW-FAT DIETS ON CARDIOMETABOLIC RISK FACTORS}

Several RCTs have investigated the effects of low-carb diets on cardiometabolic risk factors, and the effects of low-carb diets and low-fat diets have been systemically evaluated in various meta-analyses (Table 1). The carbohydrate intake range used to define lowcarb diets is inconsistent, varying between studies. Thus, the various definitions of low-carb diets must be considered when interpreting the findings. Low-carb diets can also be defined as high-fat diets. Schwingshackl and Hoffmann ${ }^{5,12}$ defined high-fat diets as acquiring $>30 \%$ of energy from fats and low-fat diets as acquiring $\leq 30 \%$ energy from fats when they compared the effects of the two diets on cardiometabolic risk factors. Naude et al. ${ }^{13}$ defined low-carb diets as obtaining $<45 \%$ of energy from carbohydrates and compared low-carb diets with balanced diets (energy intakes of $45 \%-65 \%$ carbohydrates, $25 \%-35 \%$ fats, and $10 \%-20 \%$ proteins). Diets in which carbohydrate intake is $<20 \%$ of energy, such as the Atkins diet, are sometimes referred to as "very low-carb diets." ${ }^{4}$ The most recent meta-analysis defined low-carb diets as $<40 \%$ of energy from carbohydrates and low-fat diets as $<30 \%$ of energy from fats. ${ }^{3}$

Despite differences in how carbohydrate restriction is defined, recent studies suggest that low-carb diets confer more beneficial effects on short-term weight loss and lipid profiles such as triglycerides and high-density lipoprotein (HDL) cholesterol compared to low-fat diets while having no significant effects on blood pressure or fasting blood glucose. In a recent meta-analysis of $38 \mathrm{RCTs}$ that lasted 6-12 months, participants on low-carb diets ( $<40 \%$ of energy from carbohydrates) exhibited decreased body weight and triglycerides and increased HDL cholesterol compared to participants on low-fat diets. ${ }^{3}$ Interventions with longer durations (6-24 months) and greater carbohydrate restrictions (Atkins diet or $<20 \%$ of energy) also reported similar findings. ${ }^{4}$ When compared to long-term balanced isocaloric diets, low-carb diets were associated with increased HDL cholesterol but with no significant changes in weight loss or other lipid profiles. ${ }^{13}$

Detrimental effects of low-carb diets on total and low-density lipoprotein (LDL) cholesterol levels have also been reported. Participants assigned to low-carb diets exhibited increased LDL cholesterol levels after the intervention.,4 This may be related to the high fat contents of low-carb diets. In a meta-analysis comparing the effects of low-fat and high-fat diets, the weighted mean difference did not favor the high-fat diets for total cholesterol and LDL cholesterol levels, whereas it did favor the high-fat diets for triglyceride and HDL cholesterol levels. ${ }^{5}$ 
Low-carb diets seem to confer more benefits to people with abnormal glucose metabolisms. In 2014, Schwingshackl and Hoff- mann ${ }^{12}$ conducted a meta-analysis including 14 RCTs with durations of $>1$ year and 1,753 pre-diabetic and diabetic adults; they

Table 1. The effects of low-carbohydrate diets on cardiometabolic risk factors in meta-analyses of RCTs

\begin{tabular}{|c|c|c|c|c|}
\hline Author (year) & Review period, study design, subject & $\begin{array}{l}\text { Intervention } \\
\text { duration (mo) }\end{array}$ & Intervention & $\begin{array}{l}\text { LC/HF diets vs. control diets, } \\
\text { mean difference }(95 \% \mathrm{CI})\end{array}$ \\
\hline $\begin{array}{l}\text { Schwingshackl } \\
\text { and Hoffmann } \\
(2013)^{5}\end{array}$ & $\begin{array}{c}\text { Until Mar 2013, } 32 \text { RCTs, n=8,862 } \\
\text { (overweight and obese adults) }\end{array}$ & $\geq 12$ & $\begin{array}{l}\text { HF diets: }>30 \% \text { fat } \\
\text { LF diets: } \leq 30 \% \text { fat }\end{array}$ & $\begin{array}{l}\text { HF diets } \\
\text { TG: }-8.38 \mathrm{mg} / \mathrm{dL} \text { ( }-13.50 \text { to }-3.25) \\
\text { HDL-C: }+2.35 \mathrm{mg} / \mathrm{dL} \text { (1.29 to } 3.42) \\
\text { TC: }+4.55 \mathrm{mg} / \mathrm{dL} \text { (1.07 to } 8.03) \\
\text { LDL-C: }+3.11 \mathrm{mg} / \mathrm{dL} \text { (1.71 to } 4.51)\end{array}$ \\
\hline $\begin{array}{l}\text { Schwingshackl } \\
\text { and Hoffmann } \\
(2014)^{12 *}\end{array}$ & $\begin{array}{l}\text { Until Nov 2013, } 14 \text { RCTs, } \mathrm{n}=1,753 \\
\text { (pre-diabetic and diabetic adults) }\end{array}$ & $\geq 12$ & $\begin{array}{l}\text { HF diets: }>30 \% \text { fat (>10\% saturated fat) } \\
\text { LF diets: } \leq 30 \% \text { fat, } 15 \% \text { protein, and } 55 \% \\
\text { carbohydrate }\end{array}$ & $\begin{array}{l}\text { HF diets (total subjects) } \\
\text { BW: }-0.11 \mathrm{~kg}(-1.14 \text { to } 0.91) \\
\text { SBP: }+0.59 \mathrm{mmHg}(-2.18 \text { to } 3.36) \\
\text { DBP: }-1.30 \mathrm{mmHg}(-1.73 \text { to }-0.87) \\
\text { TG: }-3.4 \mathrm{mg} / \mathrm{dL} \text { ( }-4.1 \text { to }-2.5) \\
\text { HDL-C: }+0.9 \mathrm{mg} / \mathrm{dL}(0.2 \text { to } 1.4) \\
\text { TC: }+1.3 \mathrm{mg} / \mathrm{dL} \text { (-1.8 to } 4.1) \\
\text { LDL-C: }+0.9 \mathrm{mg} / \mathrm{dL}(-1.8 \text { to } 3.6) \\
\text { FBG: }-3.2 \mathrm{mg} / \mathrm{dL} \text { ( }-9.4 \text { to } 2.7) \\
\text { HF diets (subjects with type } 2 \text { diabetes) } \\
\text { BW: }-0.47 \mathrm{~kg}(-1.85 \text { to } 0.92) \\
\text { SBP: }-1.35 \mathrm{mmHg}(-2.35 \text { to }-0.35) \\
\text { DBP: }-1.35 \mathrm{mmHg}(-1.79 \text { to }-0.92) \\
\text { TG: }-3.2 \mathrm{mg} / \mathrm{dL} \text { (-4.3 to }-2.3) \\
\text { HDL-C: }+0.7 \mathrm{mg} / \mathrm{dL}(0.0 \text { to } 1.4) \\
\text { TC: }+1.4 \mathrm{mg} / \mathrm{dL} \text { (-2.0 to } 4.9) \\
\text { LDL-C: }+0.7 \mathrm{mg} / \mathrm{dL}(-2.5 \text { to } 4.1) \\
\text { FBG: }-7.4 \mathrm{mg} / \mathrm{dL} \text { (-13.3 to }-1.4)\end{array}$ \\
\hline $\begin{array}{l}\text { Naude et al. } \\
(2014)^{13 *}\end{array}$ & $\begin{array}{l}\text { Until Mar 2014, } 19 \text { RCTs, } \mathrm{n}=3,209 \\
\text { (overweight and obese adults) }\end{array}$ & $12-24$ & $\begin{array}{l}\text { LC diets: }<45 \% \text { carbohydrate, } \\
\text { high fat variant (with unlimited fat), high protein } \\
\text { variant (with 25\%-35\% fat and > 20\% protein) } \\
\text { Balanced diets: } 45 \%-65 \% \text { carbohydrate, } 25 \%-35 \% \\
\text { fat, and 10\%-20\% protein }\end{array}$ & $\begin{array}{l}\text { LC diets for body weight (1-2 yr) } \\
\text { High fat variant: }-0.17 \mathrm{~kg}(-1.50 \text { to } 1.15) \\
\text { High protein variant: }-1.38 \mathrm{~kg}(-3.21 \text { to } 0.45) \\
\text { LC diets (overall) } \\
\text { BW: }-0.48 \mathrm{~kg}(-1.44 \text { to } 0.49) \\
\text { SBP: }-2.00 \mathrm{mmHg}(-5.00 \text { to } 1,00) \\
\text { DBP: }-0.03 \mathrm{mmHg}(-1.68 \text { to } 1.62) \\
\text { TG: }-1.1 \mathrm{mg} / \mathrm{dL}(-2.5 \text { to } 0.5) \\
\text { HDL-C: }+0.7 \mathrm{mg} / \mathrm{dL}(0.2 \text { to } 1.4) \\
\text { TC: }+1.1 \mathrm{mg} / \mathrm{dL}(-0.5 \text { to } 2.9) \\
\text { LDL-C: }+1.3 \mathrm{mg} / \mathrm{dL}(-0.2 \text { to } 2.9)\end{array}$ \\
\hline $\begin{array}{l}\text { Mansoor et al. } \\
(2016)^{4 *}\end{array}$ & $\begin{array}{l}\text { Until May 2015, } 11 \text { RCTs, } n=1,369 \\
\text { (healthy adults) }\end{array}$ & $6-24$ & $\begin{array}{l}\text { LC diets: Atkins diet }(20-40 \mathrm{~g} / \text { day of carbohydrate in } \\
\text { the first phase with gradual increases) or }<20 \% \\
\text { carbohydrate } \\
\text { LF diets: }<30 \% \text { fat }\end{array}$ & $\begin{array}{l}\text { LC diets } \\
\text { BW: }-2.17 \mathrm{~kg}(-3.36 \text { to }-0.99) \\
\text { SBP: }-1.02 \mathrm{mmHg}(-2.98 \text { to } 0.94) \\
\text { DBP: }-1.01 \mathrm{mmHg}(-2.75 \text { to } 0.74) \\
\text { TG: }-4.7 \mathrm{mg} / \mathrm{dL}(-6.7 \text { to }-2.7) \\
\text { HDL-C: }+2.5 \mathrm{mg} / \mathrm{dL} \text { (1.6 to } 3.4) \\
\text { TC: }+4.7 \mathrm{mg} / \mathrm{dL}(-1.6 \text { to } 11.2) \\
\text { LDL-C: }+2.9 \mathrm{mg} / \mathrm{dL}(0.0 \text { to } 5.9) \\
\text { FBG: }-4.1 \mathrm{mg} / \mathrm{dL} \text { (-0.9 to } 1.4)\end{array}$ \\
\hline $\begin{array}{l}\text { Chawla et al. } \\
(2020)^{3 *}\end{array}$ & $\begin{array}{l}\text { Until Sep 2019, } 38 \text { RCTs, n=6,499 } \\
\text { (adults without significant comor- } \\
\text { bidities) }\end{array}$ & $6-12$ & $\begin{array}{l}\text { LC diets: }<40 \% \text { carbohydrate } \\
\text { LF diets: }<30 \% \text { fat }\end{array}$ & $\begin{array}{l}\text { LC diets } \\
\text { BW: }-1.30 \mathrm{~kg}(-2.02 \text { to }-0.57) \\
\text { TG: }-1.8 \mathrm{mg} / \mathrm{dL}(-2.9 \text { to }-0.7) \\
\text { HDL-C: }+0.9 \mathrm{mg} / \mathrm{dL} \text { (0.5 to } 1.4) \\
\text { TC: }+1.8 \mathrm{mg} / \mathrm{dL} \text { (0.4 to } 3.2) \\
\text { LDL-C: }+1.3 \mathrm{mg} / \mathrm{dL} \text { (0.4 to } 2.2)\end{array}$ \\
\hline
\end{tabular}

*Units of blood lipid and fasting blood glucose levels in these studies were converted from mmol/L to $\mathrm{mg} / \mathrm{dL}$ for comparison.

RCT, randomized controlled trial; LC, low-carbohydrate; HF, high-fat; Cl, confidence interval; LF, low-fat; TG, triglycerides; HDL-C, high-density lipoprotein cholesterol; TC, total cholesterol; LDL-C, low-density lipoprotein cholesterol; BW, body weight; SBP, systolic blood pressure; DBP, diastolic blood pressure; FBG, fasting blood glucose. 
found significant reductions in blood pressure, triglyceride levels, and fasting blood glucose levels in subjects with type 2 diabetes assigned to a high-fat diet.

Collectively, these findings suggest that low-carb diets have double-sided effects on cardiometabolic risk factors. Low-carb diets are more effective for weight loss and improving lipid profiles, including triglycerides and HDL cholesterol levels, compared to low-fat diets. However, these effects should be weighed against the potential deleterious effects of raised LDL and total cholesterol levels.

\section{THE EFFECTS OF DIETARY}

\section{CARBOHYDRATES ON}

\section{CARDIOMETABOLIC RISK FACTORS IN THE KOREAN POPULATION}

In recent decades, researchers have actively investigated the associations between dietary carbohydrate intake and cardiometabolic risk factors such as metabolic syndrome, dyslipidemia, and diabetes in the Korean population. Table 2 presents a summary of previous observational studies evaluating dietary carbohydrate intakes as percentages of total energy. Most studies evaluated carbohydrate intake as quantiles (e.g., quintiles, quartiles, tertiles), ${ }^{7,9,14-19}$ whereas some studies categorized carbohydrate intakes into several specific ranges. ${ }^{20-23}$

Based on cross-sectional studies using data acquired by the Korea National Health and Nutrition Examination Survey (KNHANES), carbohydrate intake levels were $50 \%-56 \%$ of energy in the lowest quintile groups and $79 \%-83 \%$ of energy in the highest quintile groups among Korean adults. ${ }^{9,15,17}$ When the highest and lowest quintile groups were compared, high carbohydrate intake was associated with an increased risk of metabolic syndrome in men ${ }^{9,15}$ and women. ${ }^{9}$ In addition, people with high carbohydrate intakes had an increased risk of elevated triglyceride levels ${ }^{9,17,19}$ and lower HDL cholesterol levels, ${ }^{9,14,17,19}$ whereas they had a reduced risk of elevated to-

Table 2. The associations between dietary carbohydrate and cardiometabolic risk factors in the Korean population

\begin{tabular}{|c|c|c|c|c|c|c|}
\hline Author (year) & $\begin{array}{l}\text { Study design, } \\
\text { dataset }\end{array}$ & Subject & $\begin{array}{l}\text { Dietary assessment } \\
\text { instrument }\end{array}$ & $\begin{array}{c}\text { Dietary carbohydrate } \\
\text { (\% of energy) }\end{array}$ & Primary outcome & $\begin{array}{l}\text { Effect size }(95 \% \text { Cl) })^{*} \\
\text { (vs. Ref) }\end{array}$ \\
\hline Kim et al. (2008) $)^{14}$ & $\begin{array}{c}\text { Cross-sectional, } \\
\text { Yangpyeong }\end{array}$ & $\begin{array}{l}910 \text { Adults aged } \\
\geq 20 \mathrm{yr}\end{array}$ & FF0 (121 items) & $\begin{array}{l}\text { Quintiles (Ref: 01) } \\
\text { Men: } 58 \%, 67.5 \% \text {, and } \\
\text { 74.5\% } \\
\text { Women: } 61.6 \%, 68.7 \% \text {, } \\
\text { and } 74.2 \%\end{array}$ & $\begin{array}{l}\text { MetS and its } \\
\text { components } \\
\text { (WC, BP, } \\
\text { HDL-C, TG, } \\
\text { FBG) }\end{array}$ & $\begin{array}{l}\text { Men } \\
\text { NS } \\
\text { Women } \\
\text { MetS for 05: } 2.05(0.92-4.56) \text {; } \\
\quad P \text { for trend =0.03 } \\
\text { HDL-C for 05: } 3.54 \text { (1.69-7.40) }\end{array}$ \\
\hline Park et al. $(2010)^{20}$ & $\begin{array}{l}\text { Cross-sectional, } \\
2005 \\
\text { KNHANES }\end{array}$ & $\begin{array}{l}\text { 3,771 Adults aged } \\
20-69 \mathrm{yr}(1,536 \\
\text { men and 2,235 } \\
\text { women) }\end{array}$ & 24-hr recall & $\begin{array}{l}\text { Specific ranges } \\
<55 \%, 55 \%-70 \% \text { (Ref), } \\
\text { and }>70 \%\end{array}$ & $\begin{array}{l}\text { Obesity, BP, TG, } \\
\text { TC, HDL-C, } \\
\text { LDL-C, FBG }\end{array}$ & $\begin{array}{l}\text { Men } \\
<55 \% \text { : NS } \\
\text { TC for }>70 \% \text { : } 0.59(0.35-0.99) \\
\text { Women } \\
\text { HDL-C for }>70 \%: 1.54(1.26-1.87) \\
\text { FBG for }<55 \% \text { : } 1.74(0.36-8.32) \\
\text { FBG for }>70 \%: 2.53(1.35-4.73)\end{array}$ \\
\hline Song et al. $(2014)^{15}$ & $\begin{array}{l}\text { Cross-sectional, } \\
\text { 2007-2009 } \\
\text { KNHANES }\end{array}$ & $\begin{array}{l}6,845 \text { Adults aged } \\
30-65 \text { yr }(2,631 \\
\text { men and 4,214 } \\
\text { women) }\end{array}$ & 24-hr recall & $\begin{array}{l}\text { Quintiles (Ref: 01) } \\
\text { Men: } 54.5 \%, 62.4 \%, 67.5 \% \text {, } \\
\text { 72.3\%, and } 78.7 \% \\
\text { Women: } 56.2 \%, 65.1 \% \text {, } \\
\text { 70.4\%, } 75.2 \% \text {, and } 81.6 \%\end{array}$ & MetS & $\begin{array}{l}\text { Men } \\
\text { O5: } 1.46(1.07-2.01) \\
\text { Women } \\
\text { NS }\end{array}$ \\
\hline Song et al. $(2017)^{17}$ & $\begin{array}{l}\text { Cross-sectional, } \\
\text { 2008-2012 } \\
\text { KNHANES }\end{array}$ & $\begin{array}{l}14,301 \text { Adults aged } \\
\geq 30 \text { yr }(5,715 \\
\text { men and } 8,586 \\
\text { women) }\end{array}$ & 24-hr recall & $\begin{array}{l}\text { Quintiles (Ref: 01) } \\
\text { Men: } 51.1 \%, 62.1 \%, 68.1 \% \text {, } \\
\text { 73.4\%, and } 80.9 \% \\
\text { Women: } 53.6 \%, 64.7 \% \text {, } \\
\text { 70.4\%, } 75.8 \% \text {, and } \\
82.7 \%\end{array}$ & $\begin{array}{r}\text { Dyslipidemia } \\
\text { (TC, HDL-C, } \\
\text { LDL-C, TG) }\end{array}$ & $\begin{array}{l}\text { Men } \\
\text { HDL-C for 05: } 1.38 \text { (1.08-1.77) } \\
\text { LDL-C for 05: } 0.75(0.59-0.96) \\
\text { TG for 05: } 1.37 \text { (1.07-1.76) } \\
\text { Women } \\
\text { TC for 05: } 0.77 \text { (0.63-0.94) } \\
\text { HDL-C for 05: } 1.52(1.25-1.86) \\
\text { LDL-C for 05: } 0.88(0.71-1.09) \text {; } \\
\text { P for trend =0.039 } \\
\text { TG for 05: } 1.37(1.07-1.74)\end{array}$ \\
\hline
\end{tabular}

(Continued to the next page) 
Table 2. Continued

\begin{tabular}{|c|c|c|c|c|c|c|}
\hline Author (year) & $\begin{array}{l}\text { Study design, } \\
\text { dataset }\end{array}$ & Subject & $\begin{array}{l}\text { Dietary assessment } \\
\text { instrument }\end{array}$ & $\begin{array}{l}\text { Dietary carbohydrate } \\
\text { (\% of energy) }\end{array}$ & Primary outcome & $\begin{array}{l}\text { Effect size }(95 \% \text { CI)* } \\
\text { (vs. Ref) }\end{array}$ \\
\hline Ha et al. $(2018)^{9}$ & $\begin{array}{l}\text { Cross-sectional, } \\
\text { 2007-2012 } \\
\text { KNHANES }\end{array}$ & $\begin{array}{l}\text { 20,515 Adults aged } \\
\geq 19 \text { yr }(8,236 \\
\text { men and } 12,279 \\
\text { women) }\end{array}$ & 24-hr recall & $\begin{array}{l}\text { Quintiles (Ref: 01) } \\
\text { Men: } 50.1 \%, 61.4 \%, 67.3 \% \text {, } \\
\text { 72.8\%, and } 80.7 \% \\
\text { Women: } 51.6 \%, 63.3 \% \text {, } \\
\text { 69.4\%, } 75.0 \% \text {, and } \\
\text { 82.3\% }\end{array}$ & $\begin{array}{l}\text { MetS and its } \\
\text { components } \\
\text { (WC, BP, } \\
\text { HDL-C, TG, } \\
\text { FBG) }\end{array}$ & $\begin{array}{l}\text { Men } \\
\text { MetS for 05: } 1.32 \text { (1.01-1.73) } \\
\text { HDL-C for 05: } 1.31 \text { (1.06-1.62) } \\
\text { TG for 05: } 1.32 \text { (1.07-1.63) } \\
\text { Women } \\
\text { MetS for 05: } 1.31 \text { (1.01-1.69) } \\
\text { HDL-C for 05: } 1.45(1.21-1.74) \\
\text { TG for 05: 1.26 (1.00-1.58) }\end{array}$ \\
\hline Kwon et al. $(2018)^{18}$ & $\begin{array}{l}\text { Cross-sectional, } \\
\text { 2008-2011 } \\
\text { KNHANES }\end{array}$ & $\begin{array}{l}\text { 15,582 Adults aged } \\
20-64 \text { yr (6,732 } \\
\text { men and 8,845 } \\
\text { women) }\end{array}$ & 24-hr recall & $\begin{array}{l}\text { Tertiles (Ref: T1) } \\
\text { Men: } \leq 61.0 \%, 61.0 \%- \\
70.1 \% \text {, and } \geq 70.1 \% \\
\text { Women: } \leq 63.5 \%, 63.5 \%- \\
72.8 \% \text {, and } \geq 72.8 \%\end{array}$ & MetS & $\begin{array}{l}\text { Men } \\
\text { T3: } 1.35(1.08-1.68) \\
\text { Women } \\
\text { T3: } 1.27(1.03-1.56)\end{array}$ \\
\hline Lee et al. $(2018)^{21}$ & $\begin{array}{l}\text { Cross-sectional, } \\
\text { 2013-2015 } \\
\text { KNHANES }\end{array}$ & $\begin{array}{l}13,106 \text { Adults aged } \\
\geq 20 \text { yr }(5,966 \\
\text { men and } 7,140 \\
\text { women) }\end{array}$ & 24-hr recall & $\begin{array}{l}\text { Specific ranges } \\
<55 \% \text { (Ref), 55\%-60\%, } \\
\text { 60-65\%,65\%-70\%, } \\
\quad 70 \%-75 \%, 75-80 \% \text {, and } \\
\quad>80 \%\end{array}$ & $\begin{array}{l}\text { MetS and its } \\
\text { components } \\
\text { (WC, BP, } \\
\text { HDL-C, TG, } \\
\text { FBG) }\end{array}$ & $\begin{array}{l}\text { Men } \\
\text { FBG for } 60 \%-65 \%: 1.30(1.00-1.70) \\
\text { FBG for 70\%-75\%: } 1.27(1.00-1.60) \\
\text { TG for 60\%-65\%: } 1.27(1.00-1.61) \\
\text { TG for > 80\%: } 1.41 \text { (1.03-1.92) } \\
\text { MetS for 70\%-75\%: } 1.44(1.08-1.93) \\
\text { Women } \\
\text { HDL-C for } 75 \%-80 \%: 1.27(1.00-1.61) \\
\text { HDL-C for > 80\%: } 1.38 \text { (1.06-1.80) }\end{array}$ \\
\hline Sho et al. (2020)22 & $\begin{array}{l}\text { Cross-sectional, } \\
\text { 2016-2017 } \\
\text { KNHANES }\end{array}$ & $\begin{array}{l}\text { 7,566 Adults aged } \\
19-64 \mathrm{yr}\end{array}$ & 24-hr recall & $\begin{array}{l}\text { Specific ranges } \\
\qquad 45 \%, 45 \%-50 \%, 50 \%- \\
55 \%, 55 \%-60 \%, 60 \%- \\
65 \% \text { (Ref), 65\%-70\%, } \\
70 \%-75 \% \text {, and } \geq 75 \%\end{array}$ & $\begin{array}{l}\text { MetS and its } \\
\text { components } \\
\text { (WC, BP, } \\
\text { HDL-C, TG, } \\
\text { FBG) }\end{array}$ & $\begin{array}{l}\text { BP for }<45 \%: 1.48(1.10-2.00) \\
\text { BP for } 70 \%-75 \%: 1.25(1.00-1.55) \\
\text { HDL-C for } \geq 75 \%: 1.37(1.10-1.70)\end{array}$ \\
\hline Shin et al. $(2021)^{19}$ & $\begin{array}{l}\text { Cross-sectional, } \\
\text { HEXA study }\end{array}$ & 93,870 Adults & FFO (106 items) & $\begin{array}{l}\text { Quintiles of high-Gl } \\
\text { carbohydrate (g) (Ref: 01) }{ }^{\dagger} \\
\text { Men: } 62.6 \%, 72.0 \%, 79.8 \% \\
\text { Women: } 63.3 \%, 72.5 \% \text {, and } \\
\quad 80.4 \%\end{array}$ & $\begin{array}{r}\text { Dyslipidemia } \\
\text { (TC, HDL-C, } \\
\text { LDL-C, TG) }\end{array}$ & $\begin{array}{l}\text { Men } \\
\text { HDL-C for 05: } 1.27 \text { (1.09-1.48) } \\
\text { TG for 05: } 1.50 \text { (1.24-1.82) } \\
\text { LDL-C for 05: } 0.67(0.57-0.79) \\
\text { TC for 05: } 0.70 \text { (0.60-0.81) } \\
\text { Women } \\
\text { HDL-C for 05: } 1.51(1.31-1.74) \\
\text { TG for 05: } 1.73(1.54-1.93) \\
\text { LDL-C for 05: } 0.66(0.58-0.74) \\
\text { TC for 05: } 0.67(0.61-0.75)\end{array}$ \\
\hline Cho et al. $(2017)^{16}$ & $\begin{array}{l}\text { Longitudinal, } \\
\text { KoGES, 2-year } \\
\text { follow-up }\end{array}$ & $\begin{array}{l}\text { 5,565 Adults aged } \\
49-69 \mathrm{yr}\end{array}$ & FFO (103 items) & $\begin{array}{l}\text { Quartiles (Ref: 04) } \\
\text { 34\%-66\%, 67\%-70\%, } \\
\text { 71\%-75\%, and } 76 \%-89 \%\end{array}$ & $\begin{array}{l}\text { Incidence of } \\
\text { MetS and its } \\
\text { components }\end{array}$ & $\begin{array}{l}\text { MetS for 01: } 0.97(0.77-1.23) \\
\text { MetS for 02: } 0.77(0.61-0.97) \\
\text { HDL-C for 01: } 0.81(0.66-0.99)\end{array}$ \\
\hline Ha et al. (2019) & $\begin{array}{l}\text { Longitudinal, } \\
\text { KoGES, } \\
\text { 12-year } \\
\text { follow-up }\end{array}$ & $\begin{array}{l}\text { 5,595 Adults aged } \\
\text { 40-69 yr (2,684 } \\
\text { men and 2,911 } \\
\text { women) }\end{array}$ & FFO (103 items) & $\begin{array}{l}\text { Quartiles (Ref: 01) } \\
\text { Men: } 64.7 \%, 69.8 \%, 73.7 \% \text {, } \\
\text { and } 78.0 \% \\
\text { Women: } 66.3 \%, 71.8 \% \text {, } \\
\text { 75.6\%, and } 80.4 \%\end{array}$ & $\begin{array}{l}\text { Type } 2 \text { diabetes } \\
\text { incidence }\end{array}$ & $\begin{array}{l}\text { Men } \\
\text { Q3: } 1.40(1.02-1.93) \\
\text { 04: } 1.54(1.03-2.30) \\
\text { Women } \\
\text { 03: } 1.09(0.75-1.57) \\
\text { 04: } 1.69(1.08-2.67)\end{array}$ \\
\hline Kwon et al. $(2020)^{23}$ & $\begin{array}{l}\text { Longitudinal, } \\
\text { 2007-2015 } \\
\text { KNHANES }\end{array}$ & $\begin{array}{l}\text { 42,192 Adults aged } \\
\quad \geq 19 \mathrm{yr}\end{array}$ & 24-hr recall & $\begin{array}{l}\text { Specific ranges } \\
<50 \%, 50 \%-60 \% \text { (Ref), } \\
\quad \text { and } \geq 60 \%\end{array}$ & $\begin{array}{l}\text { All-cause } \\
\text { mortality }\end{array}$ & $\begin{array}{l}<50 \%: 1.31(1.03-1.67) \\
\geq 60 \%: 1.32(1.12-1.57)\end{array}$ \\
\hline
\end{tabular}

*Effect sizes are expressed as odds ratios for all cross-sectional studies and Cho et al. (2017)16, as relative risks for Ha et al. (2019) , and as hazard ratios for Kwon et al. (202023. †These studies presented values for the first, third, and fifth quintiles only.

$\mathrm{Cl}$, confidence interval; Ref, reference group; FFO, food frequency questionnaire; MetS, metabolic syndrome; WC, waist circumference; BP, blood pressure; HDL-C, high-density lipoprotein cholesterol; TG, triglycerides; FBG, elevated fasting blood glucose; NS, not significant; KNHANES, Korea National Health and Nutrition Examination Survey; TC, total cholesterol; LDL-C, low-density lipoprotein cholesterol; HEXA, Health Examinees; GI, glycemic index; KoGES, Korean Genome and Epidemiology Study. 
tal and LDL cholesterol levels. ${ }^{17,19}$

Several cross-sectional studies examining specific ranges of dietary carbohydrates found similar associations. ${ }^{20-22}$ Lee et al. ${ }^{21}$ categorized 13,106 adults aged 20 years or older into seven groups based on their carbohydrate intake, ranging from $<55 \%$ to $>80 \%$ of energy from carbohydrates. Then they examined associations of each group with metabolic syndrome, using the $<55 \%$ of energy group as reference. Women in the two highest carbohydrate intake groups had an increased risk of low HDL cholesterol levels, and men in the $70 \%-75 \%$ of energy group had a $44 \%$ higher risk of metabolic syndrome. Furthermore, in men, a higher risk of elevated fasting blood glucose and triglyceride levels was present in the $60 \%-75 \%$ of energy groups and $60 \%-65 \%$ and $>80 \%$ of energy groups, respectively. These findings support those of previous meta-analyses, which suggested that low-carb diets were effective at improving triglyceride and HDL cholesterol levels, but not at improving total and LDL cholesterol levels.

The groups that appeared to be associated with cardiometabolic risk factors were not just the very high-carbohydrate (high-carb) intake group. ${ }^{20,22}$ Park et al. ${ }^{20}$ found that women in the $<55 \%$ of energy from carbohydrates group had an increased risk of diabetes and low HDL cholesterol levels compared to those in the 55\%-70\% group. A recent study using the 2016-2017 KNHANES data observed that adults in both the $<45 \%$ and $70 \%-75 \%$ groups had a higher risk of elevated blood pressure than those in the 60\%-65\% group. $^{22}$

The associations between dietary carbohydrates and cardiometabolic risk factors have also been examined in longitudinally. ${ }^{7,16,23} \mathrm{~A}$ prospective cohort study with 12-year follow-ups found that middle-aged men and women in the highest quartile of carbohydrate intake (approximately $80 \%$ of energy from carbohydrates) had 1.5 and 1.7-times higher risks of incident type 2 diabetes, respectively, compared to those in the lowest quartile (65\%-66\% of energy). ${ }^{7}$ The study found a very low fat intake was also associated with an increased risk for type 2 diabetes. Another longitudinal study reported that the 2-year incidence of metabolic syndrome was lower in individuals who acquired $67 \%-70 \%$ of energy from carbohydrates compared to the $76 \%-89 \%$ of energy from carbohydrates group. ${ }^{16}$ Recently, Kwon et al. ${ }^{23}$ examined associations between dietary carbohydrate intake and all-cause mortality by linking the
2007-2015 KNHANES data with the national death index, which was followed up until 2017. They found a U-shaped association between all-cause mortality and dietary carbohydrate intake, with a minimal risk at 50\%-60\%.

Overall, the carbohydrate intake of Korean adults ranged from $50 \%-80 \%$ of energy, which was clearly higher than that of U.S. adults (35\%-65\% of energy). ${ }^{9}$ For Korean adults, a very high carbohydrate intake ( $>70 \%$ of energy) was associated with a higher risk of metabolic syndrome and type 2 diabetes, but also with a lower risk of elevated total and LDL cholesterol levels, compared to those acquiring 50\%-60\% of energy from carbohydrates.

\section{THE OPTIMAL CARBOHYDRATE INTAKE: THE LONG-TERM EFFECT ON MORTALITY}

Although numerous studies have reported the effects of low-carb diets on weight loss and/or cardiometabolic risk factors, there is still a lack of consensus as to whether low-carb diets should be recommended due to concerns about their long-term efficacy. In fact, the differences in weight loss between low-carb diets and low-fat diets were nonsignificant beyond 12 months. ${ }^{3}$

Recently, because a long-term health outcome such as mortality is not practical in clinical trials, the long-term effects of carbohydrate restriction on mortality have been investigated using cohort data. The large-scale Prospective Urban Rural Epidemiology (PURE) study examined carbohydrate intake and mortality. ${ }^{24}$ The study collected data from participants in 18 countries over five continents with various socioeconomic factors; socioeconomic factors are related to nutritional status. Nutritional excess is more common in European and North American countries, whereas undernutrition is of greater concern in other regions. This has led to a broader range of carbohydrate intakes than in other studies. They found that the highest quintile of carbohydrate intake (77.2\% of energy) was associated with a $28 \%$ increased risk of total mortality compared to the lowest quintile of carbohydrate intake (46.4\% of energy) but not with the risk of cardiovascular disease or mortality. ${ }^{24}$ In addition, total fat and saturated fat intakes were not significantly associated with risks of myocardial infarction or cardiovascular disease mortality.

Moreover, the Atherosclerosis Risk in Communities (ARIC) 
study reported that obtaining 50\%-55\% of energy from carbohydrates was associated with the lowest risk of mortality. ${ }^{25}$ They also conducted a meta-analysis of seven multinational prospective studies and found a U-shaped association between dietary carbohydrates and mortality, in which either low carbohydrate intake ( $<40 \%$ of energy) or high carbohydrate intake ( $>70 \%$ of energy) were associated with greater mortality risk than moderate carbohydrate intake (50\%-60\% of energy). ${ }^{25}$ The left side of the U-shaped curve represented the North American and European cohorts, while the right side represented Asian and multinational cohorts. ${ }^{25}$ This indicates that a moderate carbohydrate intake seems optimal in terms of minimizing the risk of mortality. In addition, Asian countries should focus on reducing carbohydrate intake, whereas North American and European countries should focus on increasing carbohydrate intakes to achieve the optimal dietary carbohydrate consumption.

\section{WHAT ARE THE CURRENT INTAKE LEVELS OF MACRONUTRIENTS IN KOREA?}

According to the secular trend of macronutrient intake in Korea over the past decade, the proportion of adults with high-carb diet ( $\geq 70 \%$ ) has decreased from $41.4 \%$ in 2010 to $23.5 \%$ in 2019 , whereas that of adults with low-carb diet $(<50 \%)$ has increased from $8.8 \%$ in 2010 to $17.0 \%$ in 2019 (Fig. 1).

Although the trend of high-carb diets is decreasing, the average intake of carbohydrates, proteins, and fats among Korean adults aged 19 years or older is $62.5 \%, 15.6 \%$, and $21.9 \%$, respectively, according to the most recent $2019 \mathrm{KNHANES}$ data. The average intake shows that Korean adults typically consume high-carb, low-fat diets. In addition, the distribution of macronutrients as percentages of energy intake varied greatly according to age and sex groups (Fig. 2 ). The proportion of adults with very low-carb intake ( $<45 \%$ of energy) by age group in men were $15.4 \%$ for $19-29$ years, $12.6 \%$ for $30-49$ years, $3.3 \%$ for $50-64$ years, $2.7 \%$ for $65-74$ years, and $0.9 \%$ for the 75 years or more. The percentages of men with very high-carb intake ( $>80 \%$ of energy) by age group were $1.5 \%$ for 19-29 years, $1.3 \%$ for $30-49$ years, $5.6 \%$ for $50-64$ years, $12.4 \%$ for $65-74$ years, and $15.9 \%$ for 75 years or more. Similar patterns were observed in women. These findings suggest that younger adults

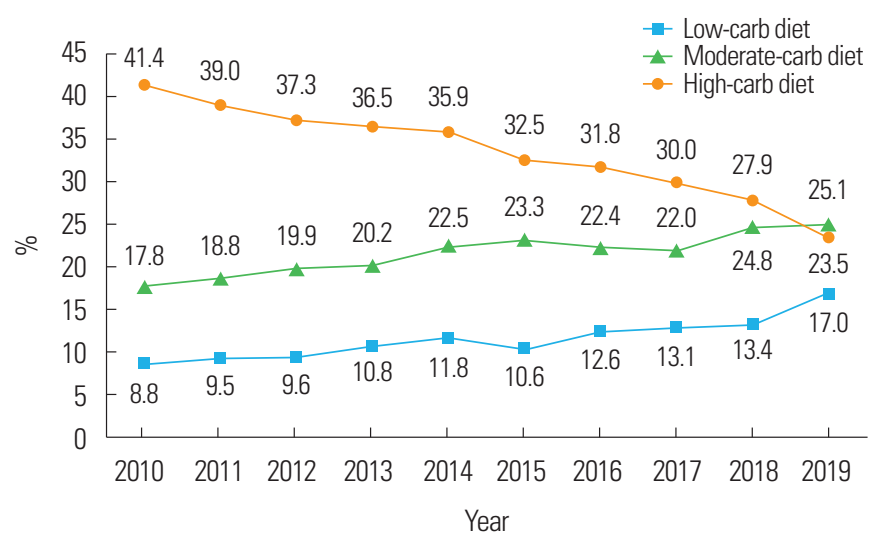

Figure 1. The secular trends in the age-standardized proportion of low-carbohydrate (carb), moderate-carbohydrate, and high-carbohydrate diets in Korean adults are shown. Data were obtained from the 2010-2019 Korea National Health and Nutrition Examination Survey $(\mathrm{n}=61,410)$. Low-carb, moderate-carb, and high-carb diets were defined as $<50 \%, 50 \%-60 \%$, and $\geq 70 \%$ of energy from carbohydrate, respectively.

were more likely to have low-carb diets, whereas older adults were more likely to have high-carb diets.

Alongside the decreased carbohydrate intake among younger adults, higher protein and total fat intakes were also present in younger populations. The proportion of adults with high protein intakes (> 20\% of energy) in the 19-29 years group was $26.4 \%$ in men and $19.3 \%$ in women, compared to $8.0 \%$ in men and $4.9 \%$ in women aged 75 years or more. The increasing total fat intake in younger people may be concerning, particularly if this is the case for saturated fats. The proportions of adults with high saturated fat intakes (> 10\% of energy) aged 19-29 years were $30.9 \%$ in men and $37.4 \%$ in women, compared to $2.0 \%$ in men and $6.9 \%$ in women aged 75 years or more. The differences in macronutrient distributions between sex and age groups suggest that dietary patterns are rapidly transitioning in Korea and that one type of diet cannot be recommended to all.

\section{WHAT IS NEXT AFTER THE LOW-CARB DIET TREND IN KOREA?}

Many people in Korea are now aware of the undesirable effects of a very high-carb intake, even if it is accompanied by a low fat intake. As a result, many people are reducing their intake of carbohydrates. However, not everyone following a low-carb diet succeeds at losing weight. One explanation for this could be that the quality 
Men
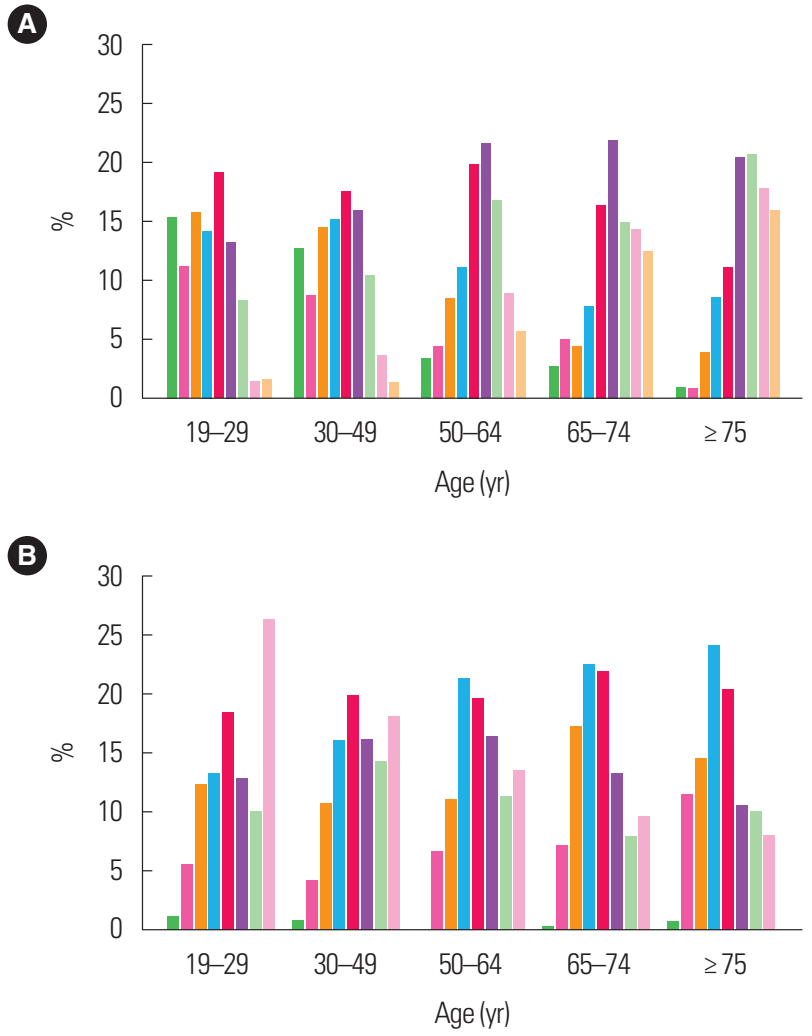

C

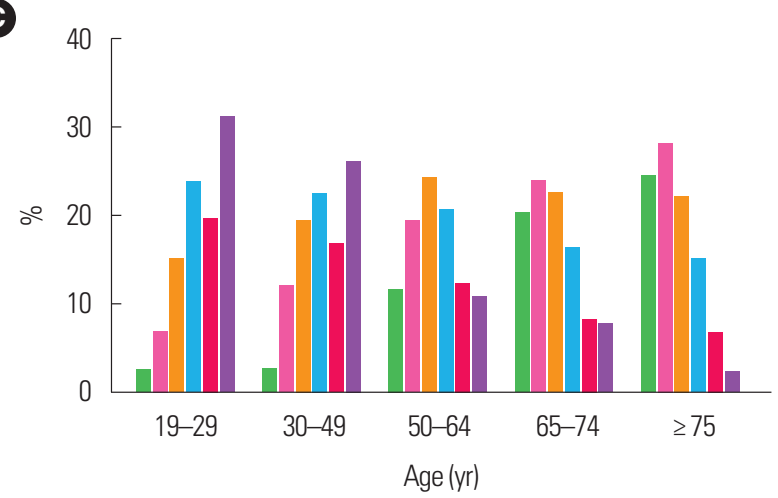

(D)

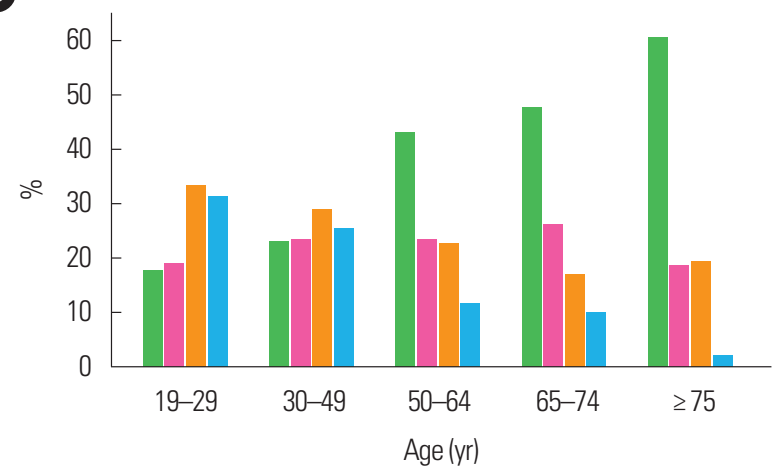

Women
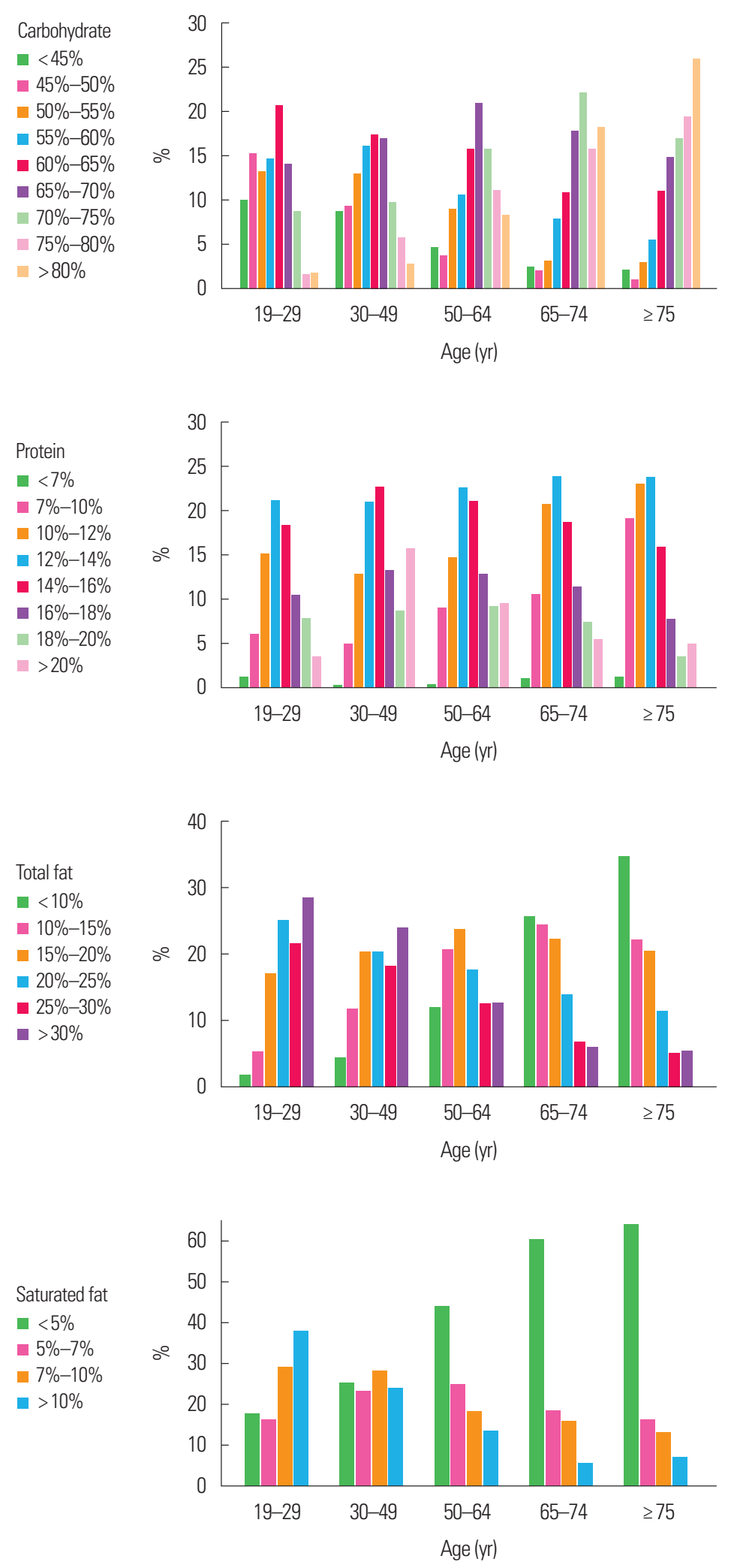

Figure 2. Distribution of Korean adults according to percentages of energy intake from (A) carbohydrate, (B) protein, (C) total fat, and (D) saturated fat by sex and age group (2,495 men and 3,277 women). Data were obtained from the 2019 Korea National Health and Nutrition Examination Survey. 
of the carbohydrates, fats, and proteins are more important than their quantity. In long-standing controversies regarding low-carb and low-fat diets, several recent studies have suggested that the health benefits of low-carb or low-fat diets may depend on the food sources of proteins and fats and the quality of carbohydrates. Shan et al. ${ }^{26}$ reported that overall low-carb and low-fat diets were not associated with total mortality in 37,233 adults from the U.S., but a healthy low-carb or low-fat diet was associated with lower total mortality, where high-quality carbohydrates were defined as carbohydrates from whole grains, whole fruit, legumes, and non-starchy vegetables, and healthy proteins and fats were defined as plant proteins and unsaturated fat. Seidelmann et al. ${ }^{25}$ reported that increased consumption of animal-based proteins and fats as replacements for carbohydrates was significantly associated with an increased risk of mortality, while consuming plant-based proteins and fats instead was significantly associated with a decreased risk of morality.

For Korean populations, diets comprising approximately $50 \%$ of energy from carbohydrates can be regarded as low-carb diets. According to the most recent 2020 Dietary Reference Intakes for Koreans (KDRIs), the recommendation for macronutrient distribution in adults is $55 \%-65 \%$ dietary carbohydrate, $15 \%-30 \%$ dietary fat, and $7 \%-20 \%$ dietary protein, which is the same level as the previous KDRIs. ${ }^{10}$ With regard to dietary carbohydrates, the estimated average requirement and recommended nutrient intake have been newly established as $100 \mathrm{~g} /$ day, $130 \mathrm{~g} /$ day, respectively, based on the evidence of $100 \mathrm{~g}$ glucose daily used in the brain in 2020 KDRIs.

Furthermore, high-protein diets are becoming more popular as individuals attempt to consume more protein than fat in place of carbohydrates. High-protein diets, in which protein intake is increased by $25 \%$ of energy, can be effective for weight loss and weight maintenance. ${ }^{27,28}$ In a study of Korean adults, the effects of moderatecarbohydrate (MC) diets (50\%-60\% of energy from carbohydrates) and high-carbohydrate (HC) diets ( $\geq 70 \%$ of energy from carbohydrates) were compared in individuals who consumed more plant protein (P) or animal protein (A). Compared to the MCP diet group, the odds ratios of metabolic syndrome in men were 1.51 (95\% confidence interval [CI], 1.02-2.22) for the MCA diet group, and 1.73 (95\% CI, 1.16-2.59) for the HCP diet group, and 2.42 (95\% CI, 1.41-4.15) for the HCA diet group; a stronger association between diet and metabolic syndrome was found in younger adults (19-49 years). ${ }^{29}$ However, the average protein intakes in the MCP and MCA diet groups were $14.2 \%$ and $18.1 \%$, which are low compared to studies of high-protein diets in Western population. High-protein diets are difficult to implement in Korea, especially diets based on plant proteins. More investigations into healthy high-protein diets with moderate carbohydrate intakes in Korean populations should be conducted.

Despite the controversies discussed above, low-fat diets are still effective for weight management in Korea. However, the quality of carbohydrates in low-fat diets should be emphasized. Higher intakes of dietary fiber and whole grains are more strongly associated with several non-communicable disease outcomes compared to measures of glycemic index or glycemic load in a dose-response manner. ${ }^{30}$ In addition, a study examining dietary fiber intake in Korean adults revealed that total fiber and fruit fiber intake were inversely associated with metabolic syndrome in men. ${ }^{31}$ This was further supported by the finding that whole fruit consumption had positive effects on obesity and metabolic syndrome in men. Another study investigating the consumption of refined grains in Korean adults found that high consumption of refined grains or white rice was associated with an increased risk of metabolic syndrome in women. ${ }^{15}$ Taken together, these studies suggest that improving dietary carbohydrate quality, such as by consuming whole grains and whole fruits, is more important in improving health outcomes than is altering the carbohydrate quantity. Moreover, they indicate that healthy low-carb diets can be achieved by focusing on consuming plant proteins, and healthy low-fat diets can be achieved by focusing on carbohydrate quality.

\section{CONCLUSION}

In summary, several meta-analyses revealed that low-carb diets are effective for short-term weight loss and improving lipid profiles, including triglycerides and HDL cholesterol levels, particularly among people with abnormal glucose metabolism. However, the positive effects of low-carb diets should be weighed against the potential deteriorative effects of raised LDL and total cholesterol levels.

Korean diets are typically classed as high-carb diets because the carbohydrate intake range of Korean adults is $50 \%-80 \%$ of energy. Within this range of carbohydrate intake, very high-carb diets ( > 70\% 
of energy) were associated with increased risks of metabolic syndrome or type 2 diabetes with decreased risks of dyslipidemia (e.g., elevated total and LDL cholesterol levels) compared to those who followed low-carb diets ( $<50 \%$ of energy). This is in line with findings from meta-analyses of RCTs.

The optimal range of carbohydrate intake was depicted by a Ushaped relationship between carbohydrate intake and mortality, with $50 \%-60 \%$ of energy from carbohydrates having the lowest mortality risk. The carbohydrate intake compromising approximately 50\% of energy from carbohydrates can be regarded as lowcarb diets in Korea. As the distribution of macronutrients varies greatly according to age and sex groups, one type of diet cannot be recommended to all. The sources and quality of proteins, fats, and carbohydrates may greatly influence the health benefits of low-carb or low-fat diets. Further studies are needed to explore the effects of long-term, sustainable diets comprising various food sources in Korea.

\section{CONFLICTS OF INTEREST}

Yoonju Song has been the Editor of the Journal of Obesity \& Metabolic Syndrome; however, she was not involved in the peer reviewer selection, evaluation, or decision process of this article. Otherwise, no other potential conflicts of interest relevant to this article are reported.

\section{ACKNOWLEDGMENTS}

This research was supported by a National Research Foundation of Korea (NRF) grant funded by the Korean Government (grant number NRF-2020R1F1A1049442).

\section{AUTHOR CONTRIBUTIONS}

Study concept and design: YS; analysis and interpretation of data: all authors; drafting of the manuscript: all authors; critical revision of the manuscript: all authors; statistical analysis: $\mathrm{KH}$; obtained funding: YS; administrative, technical, or material support: YS; and study supervision: YS.

\section{REFERENCES}

1. Astrup A, Larsen TM, Harper A. Atkins and other low-carbohydrate diets: hoax or an effective tool for weight loss? Lancet 2004;364:897-9.

2. Samaha FF, Foster GD, Makris AP. Low-carbohydrate diets, obesity, and metabolic risk factors for cardiovascular disease. Curr Atheroscler Rep 2007;9:441-7.

3. Chawla S, Silva FT, Medeiros SA, Mekary RA, Radenkovic D. The effect of low-fat and low-carbohydrate diets on weight loss and lipid levels: a systematic review and meta-analysis. Nutrients 2020;12:3774.

4. Mansoor N, Vinknes KJ, Veierød MB, Retterstøl K. Effects of low-carbohydrate diets v. low-fat diets on body weight and cardiovascular risk factors: a meta-analysis of randomised controlled trials. Br J Nutr 2016;115:466-79.

5. Schwingshackl L, Hoffmann G. Comparison of effects of long-term low-fat vs high-fat diets on blood lipid levels in overweight or obese patients: a systematic review and metaanalysis. J Acad Nutr Diet 2013;113:1640-61.

6. Hu T, Mills KT, Yao L, Demanelis K, Eloustaz M, Yancy WS $\mathrm{Jr}$, et al. Effects of low-carbohydrate diets versus low-fat diets on metabolic risk factors: a meta-analysis of randomized controlled clinical trials. Am J Epidemiol 2012;176 Suppl 7:S44-54.

7. Ha K, Joung $\mathrm{H}$, Song $\mathrm{Y}$. Inadequate fat or carbohydrate intake was associated with an increased incidence of type 2 diabetes mellitus in Korean adults: a 12-year community-based prospective cohort study. Diabetes Res Clin Pract 2019;148: 254-61.

8. Lichtenstein AH, Van Horn L. Very low fat diets. Circulation 1998;98:935-9.

9. Ha K, Kim K, Chun OK, Joung H, Song Y. Differential association of dietary carbohydrate intake with metabolic syndrome in the US and Korean adults: data from the 2007-2012 NHANES and KNHANES. Eur J Clin Nutr 2018;72:848-60.

10. Ministry of Health and Welfare; Korean Nutrition Society. Dietary reference intakes for Koreans 2020. Seoul: Korean Nutrition Society; 2020.

11. Institute of Medicine. Dietary reference intakes for energy, carbohydrate, fiber, fat, fatty acids, cholesterol, protein and 
amino acids. Washington (DC): The National Academies Press; 2005.

12. Schwingshackl L, Hoffmann G. Comparison of the long-term effects of high-fat $\mathrm{v}$. low-fat diet consumption on cardiometabolic risk factors in subjects with abnormal glucose metabolism: a systematic review and meta-analysis. Br J Nutr 2014;111: 2047-58.

13. Naude CE, Schoonees A, Senekal M, Young T, Garner P, Volmink J. Low carbohydrate versus isoenergetic balanced diets for reducing weight and cardiovascular risk: a systematic review and meta-analysis. Plos One 2014;9:e100652.

14. Kim K, Yun SH, Choi BY, Kim MK. Cross-sectional relationship between dietary carbohydrate, glycaemic index, glycaemic load and risk of the metabolic syndrome in a Korean population. Br J Nutr 2007;100:576-84.

15. Song S, Lee JE, Song WO, Paik H-Y, Song Y. Carbohydrate intake and refined-grain consumption are associated with metabolic syndrome in the Korean adult population. J Acad Nutr Diet 2014;114:54-62.

16. Cho NH, Cho AK, Kim HK, Kim JB, Lee KE, Kim SS, et al. Carbohydrate composition associated with the 2-year incidence of metabolic syndrome in Korean adults. Clin Nutr Res 2017; 6:122-9.

17. Song S, Song WO, Song Y. Dietary carbohydrate and fat intakes are differentially associated with lipid abnormalities in Korean adults. J Clin Lipidol 2017;11:338-47.e3.

18. Kwon YJ, Lee HS, Lee JW. Association of carbohydrate and fat intake with metabolic syndrome. Clin Nutr 2018;37:746-51.

19. Shin W, Shin S, Lee J, Kang D, Lee JE. Carbohydrate intake and hyperlipidemia among population with high-carbohydrate diets: The Health Examinees Gem Study. Mol Nutr Food Res 2021;65:2000379.

20. Park SH, Lee KS, Park HY. Dietary carbohydrate intake is associated with cardiovascular disease risk in Korean: analysis of the third Korea National Health and Nutrition Examination Survey (KNHANES III). Int J Cardiol 2010;139:234-40.

21. Lee YJ, Song S, Song Y. High-carbohydrate diets and food patterns and their associations with metabolic disease in the
Korean population, Yonsei Med J 2018;59:834-42.

22. Soh SM, Chung SJ, Yoon J. dietary and health characteristics of Korean adults according to the level of energy intake from carbohydrate: analysis of the 7th (2016-2017) Korea National Health and Nutrition Examination Survey Data. Nutrients 2020;12:429.

23. Kwon YJ, Lee HS, Park JY, Lee JW. Associating intake proportion of carbohydrate, fat, and protein with all-cause mortality in Korean adults. Nutrients 2020;12:3208.

24. Dehghan M, Mente A, Zhang X, Swaminathan S, Li W, Mohan $\mathrm{V}$, et al. Associations of fats and carbohydrate intake with cardiovascular disease and mortality in 18 countries from five continents (PURE): a prospective cohort study. Lancet 2017; 390:2050-62.

25. Seidelmann SB, Claggett B, Cheng S, Henglin M, Shah A, Steffen LM, et al. Dietary carbohydrate intake and mortality: a prospective cohort study and meta-analysis. Lancet Public Health 2018;3:e419-28.

26. Shan Z, Guo Y, Hu FB, Liu L, Qi Q. Association of low-carbohydrate and low-fat diets with mortality among US adults. JAMA Intern Med 2020;180:513-23.

27. Larsen TM, Dalskov SM, Baak M van, Jebb SA, Papadaki A, Pfeiffer AF, et al. Diets with high or low protein content and glycemic index for weight-loss maintenance. N Engl J Med 2010;363:2102-13.

28. Moon J, Koh G. Clinical evidence and mechanisms of highprotein diet-induced weight loss. J Obes Metab Syndr 2020; 29:166-73.

29. Ha K, Nam K, Song Y. A moderate-carbohydrate diet with plant protein is inversely associated with cardiovascular risk factors: the Korea National Health and Nutrition Examination Survey 2013-2017. Nutr J 2020;19:84.

30. Reynolds A, Mann J, Cummings J, Winter N, Mete E, Morenga LT. Carbohydrate quality and human health: a series of systematic reviews and meta-analyses. Lancet 2019;393:434-45.

31. Song S, Song Y. Dietary fiber and its source are associated with cardiovascular risk factors in Korean adults. Nutrients 2021; 13:160. 